\title{
Wieloletnia prognoza finansowa jako instrument zarządzania finansami samorządowymi
}

\author{
Zofia Dolewka \\ Dr, Uniwersytet Łódzki, \\ Wydział Ekonomiczno-Socjologiczny \\ Katedra Samorządu Terytorialnego \\ http://dx.doi.org/10.18778/8088-114-3.18
}

\section{Wprowadzenie}

Konieczność dostosowania polskiego prawa w zakresie gospodarowania finansami publicznymi do poziomu Unii Europejskiej ${ }^{1}$ spowodowała wprowadzenie $\mathrm{w}$ życie nowej ustawy o finansach publicznych z $2009 \mathrm{r}^{2}$ Jednym z głównych celów tej regulacji prawnej było m.in. wprowadzenie obligatoryjnego obowiązku, związanego $\mathrm{z}$ wieloletnim planowaniem finansowym zarówno na poziomie centralnym, jak i regionalnym oraz lokalnym. Planowanie wieloletnie uznawane jest przez współczesną naukę za niezbędny instrument nowoczesnego zarządzania finansami publicznymi. Należy podkreślić, że do 2010 r. niektóre jednostki samorządu terytorialnego opracowywały i tym samym dysponowały wymienionym instrumentem. Dokument ten nazywany był m.in. wieloletnim planem finansowym bądź wieloletnim programem finansowym. Jednakże było to podejście fakultatywne, nie wynikało z przepisów prawa.

Uwzględniając fakt, iż budżety jednostek samorządu terytorialnego (podobnie jak budżet państwa) są planami jednorocznymi, to wieloletnie planowanie finansowe stanowi nie tylko przejaw planowania strategicznego, ale czegoś niezbędnego i komplementarnego do budżetu. Trudno bowiem zarządzać jednostką w perspektywie jednego roku, bowiem wtedy można tylko administrować. Rozwój jednostki wymaga powiązania

1 Budżet UE oparty jest na wieloletnim planie finansowym. Planowanie wieloletnie jest niezbędnym instrumentem nowoczesnego zarządzania finansami publicznymi. Jego zalety akcentowane są w opracowaniach i raportach takich instytucji, jak Bank Światowy i Organizacja Współpracy Gospodarczej i Rozwoju (OECD).

2 Ustawa z dnia 27 sierpnia 2009 r. o finansach publicznych (Dz.U. z 2013 r., poz. 885 ze zm.), która zaczęła obowiązywać od 1 stycznia 2010 r. 
wydatków budżetowych ze średnio i długookresowymi celami oraz $\mathrm{z}$ kondycją finansową $\mathrm{w}$ dłuższej perspektywie.

Wspomniana wcześniej ustawa o finansach publicznych z 2009 r. wprowadziła obowiązek opracowywania na poziomie państwa wieloletniego planu finansowego państwa (WPFP), zaś na poziomie samorządu terytorialnego - wieloletniej prognozy finansowej (WPF). Wieloletnia prognoza finansowa $\mathrm{z}$ założenia miała być dokumentem strategicznym, wieloletnim, stanowiącym podstawę rozwoju samorządu. Miała być wdrażana w celu przeprowadzenia oceny sytuacji finansowej jednostki samorządu terytorialnego przez jej organy uchwałodawcze (stanowiące), mieszkańców, instytucje finansowe, organy nadzoru oraz wszystkich pozostałych zainteresowanych. Dane budżetowe, obrazujące sytuację finansową jednostki samorządowej w przyszłych latach, pozwalają na dokonanie analizy możliwości inwestycyjnych oraz oceny zdolności kredytowej. Jednym z głównych celów przygotowania wieloletniej prognozy finansowej było umożliwienie weryfikacji długookresowej stabilności finansowej jednostki samorządu terytorialnego. Jednakże praktyka dostarcza wiele problemów i wątpliwości dotyczących m.in. prawidłowości danych wykazywanych w tym dokumencie, uwzględniając kontekst czasu, na jaki był $i$ jest sporządzany.

Celem artykułu jest dokonanie oceny tego narzędzia z punktu widzenia jego zastosowania i realistyczności. Całość rozważań zostanie przeprowadzona w oparciu o analizę wybranej literatury specjalistycznej, przepisów prawa odnoszących się do sytemu finansów publicznych w Polsce oraz danych w zakresie opracowywania wieloletniej prognozy finansowej w 18 miastach wojewódzkich.

\section{Wieloletnia prognoza finansowa jako narzędzie planistyczne}

Omawiając kwestię planowania, należy zwrócić uwagę na związki i różnice pomiędzy planowaniem a prognozowaniem. Plan jest określeniem sposobu postępowania, jest programem działań, zaś prognoza jest przewidywaniem procesów od nas niezależnych. Plan dotyczy więc tych procesów i elementów, co do których możemy dokonywać wyboru (podejmować decyzję). Prognoza określa jedynie przyszły stan procesów lub zjawisk ekonomicznych, nie zakładając żadnej ingerencji w ten stan poprzez decyzje i planowe działania. Plan oceniany jest z punktu widzenia efektywności i skutków uzyskanych dzięki tym działaniom, prognoza 
oceniana jest jedynie z punktu widzenia jej trafności. Należy pamiętać, że prognoza niesie ze sobą ryzyka, stąd konieczność stosowania tzw. zasady ograniczonego zaufania. Reasumując, prognozowanie i planowanie są ze sobą $\mathrm{w}$ procesie zarządzania powiązane, jednakże nie należy ich ze sobą utożsamiać3.

Choć planowanie wieloletnie jest zazwyczaj kojarzone $\mathrm{z}$ poziomem budżetu państwa jako jeden $\mathrm{z}$ istotniejszych mechanizmów racjonalizowania wyborów $\mathrm{w}$ polityce finansowej, to $\mathrm{w}$ wielu państwach, także w samorządach funkcjonuje mechanizm planowania w perspektywie kilku lat. Tak jest m.in. w Danii, w Belgii, w Portugalii, w Nowej Zelandii, czy w Stanach Zjednoczonych. W Polsce, jak już wcześniej wspomniano, w świetle obowiązujących przepisów prawa, na poziomie centralnym to Rada Ministrów uchwala wieloletni plan finansowy państwa (WPFP) i ogłasza go w Dzienniku Urzędowym Rzeczypospolitej Polskiej „Monitor Polski” oraz w Biuletynie Informacji Publicznej. Jest to dokument, który obejmuje cztery lata budżetowe, tj. dany rok budżetowy i trzy kolejne lata ${ }^{4}$. Stanowi plan dochodów i wydatków oraz przychodów i rozchodów państwa. Dane w nim zawarte są bazą do przygotowania projektu ustawy budżetowej na kolejny rok. Wieloletni plan finansowy państwa jest aktualizowany przez Radę Ministrów w drodze uchwały, corocznie, w terminie dwóch miesięcy od dnia ogłoszenia ustawy budżetowej, i uwzględnia prognozę na kolejne trzy lata. Aktualizacja WPFP polega na doprowadzeniu danych $\mathrm{w}$ nim zawartych do zgodności z ustawą budżetową na dany rok budżetowy, a także na skorygowaniu WPFP w dalszych latach jego realizacji, w celu zapewnienia zgodności z kierunkami polityki społeczno-gospodarczej i ze średniookresową strategią rozwoju kraju.

Z kolei dla samorządu terytorialnego w zakresie wieloletniego planowania, ustawodawca $w$ tej samej regulacji prawnej ${ }^{5}$ wprowadził instytucję wieloletniej prognozy finansowej (WPF). Uchwalenie tego dokumentu należy do obowiązków organów stanowiących. Według L. Patrzałka, wieloletnia prognoza finansowa jest opisem zamierzonych, w perspektywie co najmniej trzech lat, wewnętrznie spójnych działań organów samorządu terytorialnego, związanych z gromadzeniem i rozdysponowaniem zasobów pieniężnych pod kątem osiągania wyznaczonych celów, związanych z organizowaniem i udostępnianiem dóbr publicznych i społecznych ${ }^{6}$. Dokument ten jest prognozą kroczącą, czyli uzupełnianą (przedłużaną)

3 Pojęcia „plan” i „prognoza” nie są synonimami. Plan to pewien program zadań i prac, które mają być wykonane (są przewidziane do wykonania) w określonym czasie. Prognoza natomiast zawiera przewidywania oparte na określonych danych, obliczeniach; za: Nowy słownik języka polskiego, red. E. Sobol, Warszawa 2002, s. 666 i 753.

4 Art. 103 ustawy z dnia 27 sierpnia 2009 r. o finansach publicznych.

5 Ibidem, art. 226.

6 L. Patrzałek, Finanse samorzqdu terytorialnego, Wrocław 2010, s. 116-117. 
na kolejny rok budżetowy tak, by każdorazowo obejmował rok budżetowy i co najmniej trzy kolejne lata ${ }^{7}$. Czteroletni okres obowiązywania jest terminem minimalnym. Oznacza to, że nie jest możliwe uchwalenie WPF obejmującej okres, np. dwu albo trzyletni. Przepisy prawa nie zakreślają natomiast górnego limitu czasowego obowiązywania WPF, zastrzegając jedynie, że okres ten nie może być krótszy niż okres, na który zaciągnięto oraz planuje się zaciągnąć zobowiązania. S. Owsiak twierdzi, że planowanie finansowe (budżetowe) w gruncie rzeczy jest odmianą tzw. planowania kroczącego, czyli takiego, w którym dokonuje się urealnienia planowanych wielkości finansowych i ogólnie makroekonomicznych w zależności od rozwoju sytuacji gospodarczej i społecznej kraju.

Okres planowania finansowego ma istotny wpływ na realność danych zawartych w takim dokumencie. Trzeba dodać, że samo sformułowanie „prognoza ma być realistyczna” jest nieostre, a ocena spełnienia tego wymogu prawnego przez organ nadzoru jest bardzo utrudniona, mając chociażby na względzie horyzont czasowy prognozy. Prognoza spełnia warunek realizmu, jeżeli na etapie przygotowywania i uchwalania opiera się na starannie i obiektywnie opracowanych wartościach. Realizm WPF oznacza, że - aby tworzyć warunki do prowadzenia racjonalnej, odpowiedzialnej i relatywnie stabilnej polityki finansowej - powinna ona uwzględniać zdarzenia, które mają lub mogą mieć wpływ na gospodarkę finansową jednostek samorządu terytorialnego w perspektywie czasu wykraczającej poza bieżący rok budżetowy, w tym również możliwości wystąpienia zjawisk nieoczekiwanych9. Chcąc spełniać ustawowy wymóg realności, prognoza powinna być weryfikowana i przygotowana w oparciu o prawidłowe założenia metodologiczne - bez zaniżania lub zawyżania projektowanych wartości. Opis przyjętej metodologii, w tym np. stosowanych metod ekonometrycznych, powinien znaleźć się w objaśnieniach do $\mathrm{WPF}^{10}$.

Wiadomym jest, że im dłuższy okres, tym mniejsza realność. Jak podaje ministerstwo finansów, w ponad $88 \%$ przypadków WPF sporządzono dla okresu dłuższego niż 4 lata ${ }^{11}$. Prognozy opracowane dla okresu od 5 do 10 lat stanowią blisko $43 \%$, zaś pozostałe $45 \%$ - obejmują więcej niż 10 lat. Jak przedstawia się sytuacja w tym zakresie w miastach wojewódzkich obrazuje tabela 1 . W badanych jednostkach ustawowy wy-

7 Art. 227 ust. 1 ustawy z dnia 27 sierpnia 2009 r. o finansach publicznych.

8 S. Owsiak, Wieloletnie planowanie finansowe a funkcjonowanie budżetu zadaniowego, „Studia BAS” 2013, nr 1 (33), s. 43.

9 Wahań koniunktury, kryzysu gospodarczego, działania sił natury i innych zdarzeń losowych.

10 Art. 226 ust. 1 pkt 7 ustawy z dnia 27 sierpnia 2009 r. o finansach publicznych.

$11 \mathrm{http}: / /$ www.finanse.mf.gov.pl/budzet-panstwa/finanse-samorzadow/komunikaty/-/asset_publisher/5lkj/content. (dostęp 30.07.2015 r.). 
móg realistyczności WPF ${ }^{12}$ nie jest zadaniem prostym, bowiem trudno odpowiedzialnie mówić o realistyczności w perspektywie 10, 15 i więcej lat, uwzględniając przy tym bardzo zmienne otoczenie w jakim funkcjonujemy. Z danych (tab. 1) widać, że osiem największych miast w Polsce ${ }^{13}$ sporządza ten dokument dla okresu obowiązywania ponad 25 lat (w tym Kraków 37 lat). Oczywiście dotyczy to tej części WPF, która odnosi się do prognozy kwoty długu.

Ponadto, zdaniem E. Kuzyniak, gminy, starając się wykazać w wieloletnich prognozach finansowych spełnienie wymogów art. 243 ustawy o finansach publicznych, zamiast podejmować realne kroki naprawcze ulegają pokusie zbyt optymistycznego planowania dochodów i wydatków ${ }^{14}$. Jak już wcześniej wspomniano, przy wyborze zbyt długiego horyzontu planowania prognoza obarczona jest zdecydowanie większym błędem. Warto w tym miejscu zaznaczyć, że w krajach skandynawskich, samorządy sporządzają plany finansowe na okres trzech lub czterech lat, z monitorowaniem poziomu deficytu. Z kolei samorządy w Belgii iw Portugalii wieloletnie plany finansowe opracowują na czas kadencji organu stanowiącego. Takie podejście jest jak najbardziej uzasadnione i to z kilku powodów. Przede wszystkim, mimo że wieloletnie planowanie finansowe ma charakter prognostyczny, to z perspektywy trzech, czterech lat jest dokumentem bardziej realistycznym niż te ze zbyt długim horyzontem czasowym (kilkanaście lat).

\begin{tabular}{|l|l|c|c|c|}
\hline \multirow{2}{*}{ Miasta } & \multirow{2}{*}{$\begin{array}{c}\text { Czas obowią- } \\
\text { zywania WPF }\end{array}$} & \multicolumn{3}{c|}{ Dokonywane zmiany w WPF w ciągu roku } \\
\cline { 3 - 5 } & 2013 & 2014 & do 15 lipca 2015 \\
\hline Białystok & $2015-2038$ & 11 & 11 & 5 \\
\hline Bydgoszcz & $2015-2036$ & 8 & 8 & 0 \\
\hline Gdańsk & $2015-2040$ & brak danych & brak danych & brak danych \\
\hline Gorzów Wielkopolski & $2015-2030$ & brak danych & brak danych & brak danych \\
\hline Katowice & $2015-2035$ & 25 & 11 & brak danych \\
\hline Kielce & $2015-2030$ & brak danych & brak danych & brak danych \\
\hline Kraków & $2015-2052$ & 10 & 12 & 7 \\
\hline Lublin & $2015-2035$ & 14 & 10 & 7 \\
\hline tódź & $2015-2040$ & 16 & 20 & 7 \\
\hline Olsztyn & $2015-2029$ & 13 & 10 & 4 \\
\hline Opole & $2015-2036$ & 12 & 10 & 4 \\
\hline Poznań & $2015-2041$ & 6 & 5 & 1 \\
\hline
\end{tabular}

12 Art. 226 ust. 1 ustawy z dnia 27 sierpnia 2009 r. o finansach publicznych.

13 Dotyczy to takich miast jak Warszawa, Kraków, Łódź, Wrocław, Poznań, Gdańsk, Szczecin, Toruń.

14 E. Kuzyniak, Wirtualne dochody nie rozwiq̨żą problemów wskaźnika zadłużenia, „Wspólnota” 2013, nr 20. 


\begin{tabular}{|l|l|c|c|c|}
\hline \multirow{2}{*}{ Miasta } & \multirow{2}{*}{$\begin{array}{c}\text { Czas obowią- } \\
\text { zzwania WPF }\end{array}$} & \multicolumn{3}{|c|}{ Dokonywane zmiany w WPF w ciągu roku } \\
\cline { 3 - 5 } & $2015-2021$ & brak danych & brak danych & brak danych \\
\hline Rzeszów & $2015-2043$ & 6 & 4 & 2 \\
\hline Szczecin & $2015-2040$ & 8 & 7 & 1 \\
\hline Toruń & $2015-2042$ & brak danych & brak danych & brak danych \\
\hline Warszawa & $2015-2043$ & 10 & 8 & 3 \\
\hline Wrocław & $2015-2034$ & 15 & 13 & 10 \\
\hline Zielona Góra & & 15 & 8015 \\
\hline
\end{tabular}

Tabela 1. WPF miast wojewódzkich wg okresu planowania i dokonywanych zmian Źródło: opracowanie własne na podstawie danych z BIP poszczególnych urzędów miast.

Analizując dane dotyczące dokonywanych w ciągu roku zmian w budżecie danej jednostki samorządowej i jednocześnie w wieloletniej prognozie finansowej, stwierdza się, że dokument, który miał być z założenia planem ogólnym (WPF), pełniącym funkcje nadrzędne w stosunku do rocznego budżetu, pozostaje dokumentem wtórnym w odniesieniu do uchwały budżetowej. Jest on zmieniany w obszarze podstawowych założeń, w zależności od decyzji władz samorządowych podejmowanych w procedurze uchwalania budżetu. Z informacji zawartych w tabeli wynika, że spośród 15 jednostek, aż 9 w 2013 r. i 8 w 2014 r. dokonywało zmian w ciągu roku budżetowego w WPF dziesięciokrotnie lub więcej razy $^{15}$. Nie ulega wątpliwości, że dokument ten, zgodnie z jego ustawowym wymogiem realności, powinien być aktualizowany. Pytanie brzmi - jak często? Czy tylko na etapie uchwalania budżetu, czy również w sytuacji dokonywania zmian w budżecie? $Z$ obserwacji widać, że dotyczy to drugiego wariantu, a to z kolei wypacza przydatność wieloletniej prognozy finansowej, jako narzędzia zarządzania finansami samorządowymi. Jeśli WPF może tak często ulegać zmianom w ciągu jednego roku bazowego - i to w znacznym zakresie, to nie można tego dokumentu traktować poważnie ${ }^{16}$. Bardzo częste zmiany dokonywane przez samorządy pokazują, że z realnością prognozy nie mają nic wspólnego, oczywiście poza danymi dotyczącymi bieżącego roku budżetowego - pokrywającymi się $\mathrm{z}$ budżetem ${ }^{17}$.

15 Rekordziści w tym względzie to Katowice (25 razy w 2013 r.) i Łódź (20 razy w 2014 r.).

16 Zob. C. Kosikowski, Reforma finansów w Polsce w świetle nowej ustawy o finansach publicznych, „Państwo i Prawo” 2009, nr 12.

17 E. Czołpińska, Wieloletnia prognoza finansowa - doświadczenia po roku stosowania. Przewidywania, praktyka i wnioski de lege ferenda, http://www.samorzad. lex.pl (dostęp 31.07.2015 r.). 


\section{Ocena przydatności wieloletniej prognozy finansowej i propozycje zmian}

W organizacjach publicznych podstawą działania są dokumenty o charakterze strategicznym. Ich ważność i rola polega na określeniu celów i zadań w dłuższej perspektywie czasowej. Z tego punktu widzenia dokumenty te mogą być traktowane jako swoiste narzędzia realizacyjne. Każdy podmiot gospodarowania (a samorząd jest takim podmiotem) powinien myśleć i działać według strategii długofalowych. Wiąże się to wszystko z wyzwaniami, które płyną z bliższego i z dalszego otoczenia. Cele i zadania w samorządzie mobilizują do działania, ale jednocześnie narzucają ograniczenia i reżimy. Przez długi czas dokumenty strategiczne nie obejmowały sfery finansów, a bardziej odnosiły się do obszarów zarządzania.

Niewątpliwie wieloletnia prognoza finansowa - jako element planowania wieloletniego - jest potrzebna i wprowadzenie jej jako powszechnego obowiązku służb finansowych jednostek samorządu terytorialnego należy uznać za zasadne. Opracowanie tego dokumentu wiąże się z bardziej pogłębioną (niż to miało i ma miejsce przy sporządzaniu budżetu na okres jednego roku) analizą finansów jednostki samorządowej w perspektywie wieloletniej, ze szczególnym uwzględnieniem m.in. wydatków bieżących oraz wysokości długu i ewentualnych możliwości dalszego zadłużania się. Jak już wcześniej była mowa, planowanie wieloletnie nie jest niczym nowym w praktyce funkcjonowania wielu jednostek samorządu terytorialnego. Aplikując o środki pozabudżetowe (przede wszystkim pochodzące z programów europejskich), jednostki samorządowe musiały spełniać wymogi formalne, jakim była m.in. konieczność posiadania wieloletniej prognozy.

Treść WPF powinna sprzyjać ocenie kondycji finansowej jednostek samorządowych, bowiem zobowiązuje je do ujęcia ważnych danych finansowych. Po pierwsze, w dokumencie tym mają być zawarte informacje na temat dochodów i wydatków bieżących, z podaniem wydatków na obsługę długu. Pozwala to ocenę bieżącej równowagi i wskazuje na rezerwy - bądź ich brak, na prowadzenie działalności inwestycyjnej. Po drugie, w prognozie trzeba ująć również dochody i wydatki majątkowe, a to z kolei pozwoli ocenić realność zamierzeń inwestycyjnych. Po trzecie, określenie na każdy rok budżetowy wyniku budżetu, daje istotną informację w zakresie kierunków przeznaczenia nadwyżki (w przypadku dodatniego wyniku) lub sposobu sfinansowania deficytu (w przypadku ujemnego wyniku). Oprócz wymienionych danych finansowych w WPF musi być także m.in. zawarta kwota długu oraz sposób sfinansowania jego spłaty. Te istotne wielkości, charakteryzujące sytuację finansową jednostki samorządowej, są ważne nie tylko z punktu widzenia zarządzania finansami, ale całą jednostką. Sytuacja finansowa będzie rzutować w prostej 
linii na zaspokajanie potrzeb społeczności wspólnoty, czyli na realizację zadań publicznych, zarówno w sferze infrastrukturalnej jak i socjalnej.

Przy sporządzaniu WPF na pierwszy plan wysuwa się oczywiście przygotowywanie projektu uchwały budżetowej. Następnie ważne jest opracowanie metodologii prognozowania lub planowania poszczególnych wielkości wchodzących w skład WPF (m.in. wielkości budżetowych, przedsięwzięć, długu). Przyjęta metodologia powinna być właściwie dobrana do szacowania poszczególnych wielkości, chodzi tu zarówno o stopień skomplikowania danej metody, jak i dostępność danych niezbędnych do użycia ${ }^{18}$. Niestabilność polskiej gospodarki oraz chociażby niestabilność samego WPFP ${ }^{19}$, nie pozwala na bezkrytyczne jego traktowanie, jako bazy do przyjęcia realnych wielkości na potrzeby WPF.

Kolejną kwestią jest określenie ram czasowych WPF. Obowiązek prezentowania wskaźników na okres spłaty długu, powoduje konieczność planowania m.in. takich wielkości jak: dochody ogółem, dochody bieżące, dochody majątkowe (sprzedaż majątku), wydatki ogółem, wydatki bieżące. W tym przypadku kluczowa jest definicja wspomnianej już wcześniej „realistyczności” prognozy. Z obserwacji wynika, że jednostki samorządowe przyjmują założenie stałości podstawowych wielkości WPF po określonym czasie (np. 4 lat). I w tym miejscu powstaje pytanie: po co prezentować prognozę w tak odległym horyzoncie czasowym (ponad 10 lat), skoro jedynym rozsądnym założeniem jest przyjęcie stałości elementów powyżej pewnego okresu? Niektórzy fachowcy uważają, że daje to WPF walor kompletności analizy. Jest to pewne uzasadnienie, ale przy analizie prognozy wcześniej wymienionych 18 miast nasuwa się szereg wątpliwości. Trudno bowiem ich nie mieć, gdy jednostka samorządowa mając zadłużenie stanowiące ok. 78\% planowanych dochodów budżetowych, w uchwalonej prognozie finansowej na lata 2015-2040 przyjmuje, że:

- tylko w 2015 r. wynik budżetu będzie ujemny, w dalszych latach (do 2040) zawsze dodatni,

- korzystanie z instrumentów dłużnych tylko do 2017 r. (włącznie), po 2017 r. aż do 2040 - nie przewiduje się,

- z każdym rokiem planuje się osiągnięcie nadwyżki operacyjnej na coraz wyższym poziomie (od 2023 r. wyraźna tendencja wzrostowa),

- najwyższy poziom wydatków majątkowych w 2015 r. a od 2016 r. ich wartość istotnie maleje,

- całkowita spłata długu w 2040 r.,

- dochody ze sprzedaży majątku zaplanowane corocznie do 2040 r.

18 Zob. J. Sierak, Wieloletnie planowanie finansowe w jednostkach samorzadu terytorialnego, saf.ews21.pl/download/lectures/0/000/000/001/wykladwpffffff.pdf, (dostęp 1.08.2015 r.).

19 Wynika to z brzmienia art. 107 ustawy z dnia 27 sierpnia 2009 r. o finansach publicznych. 
Uwzględniając zamierzenia rozwojowe tej jednostki, jak również potrzeby społeczne i infrastrukturalne, nie ma żadnej wątpliwości, że ten dokument nie jest realistyczny, nawet co do przyjętych wielkości w latach 2016-2018.

Z punktu widzenia wykonywania zadań publicznych ważne jest, aby możliwości finansowe jednostki samorządowej pozwalały konsekwentnie dążyć do realizacji zaplanowanych celów. Jednak nie zawsze uzyskiwane dochody wystarczają na pokrycie wydatków. W literaturze przedmiotu wskazuje się wiele przyczyn powstawania deficytu budżetowego. Według M. Jastrzębskiej powodem jest m.in. malejąca baza dochodowa (np. na skutek spadku liczby mieszkańców), nieadekwatność transferów $z$ budżetu państwa do przekazanych zadań ${ }^{20}$. Na podstawie danych zaczerpniętych $\mathrm{z}$ wieloletnich prognoz finansowych badanych miast, $w$ tabeli 2 przedstawiono występowanie deficytu lub nadwyżki budżetowej.

\begin{tabular}{|l|c|c|c|c|}
\hline \multirow{2}{*}{ Miasta } & \multicolumn{4}{c|}{ Lata } \\
\cline { 2 - 5 } & 2015 & 2016 & 2017 & 2018 \\
\hline Białystok & deficyt & nadwyżka & nadwyżka & nadwyżka \\
\hline Bydgoszcz & deficyt & deficyt & deficyt & nadwyżka \\
\hline Gdańsk & nadwyżka & deficyt & nadwyżka & nadwyżka \\
\hline Gorzów Wielkopolski & deficyt & deficyt & deficyt & deficyt \\
\hline Katowice & deficyt & nadwyżka & nadwyżka & nadwyżka \\
\hline Kielce & deficyt & deficyt & deficyt & nadwyżka \\
\hline Kraków & deficyt & nadwyżka & nadwyżka & deficyt \\
\hline Lublin & deficyt & deficyt & deficyt & nadwyżka \\
\hline Łódź & deficyt & nadwyżka & nadwyżka & nadwyżka \\
\hline Olsztyn & deficyt & deficyt & deficyt & nadwyżka \\
\hline Opole & deficyt & deficyt & deficyt & deficyt \\
\hline Poznań & deficyt & deficyt & nadwyżka & nadwyżka \\
\hline Rzeszów & deficyt & deficyt & deficyt & deficyt \\
\hline Szczecin & deficyt & nadwyżka & deficyt & deficyt \\
\hline Toruń & nadwyżka & deficyt & deficyt & deficyt \\
\hline Warszawa & deficyt & deficyt & deficyt & deficyt \\
\hline Wrocław & deficyt & deficyt & deficyt & deficyt \\
\hline Zielona Góra & deficyt & nadwyżka & nadwyżka & nadwyżka \\
\hline
\end{tabular}

Tabela 2. Wynik budżetu miast wojewódzkich w latach 2015-2018 Źródło: opracowanie własne na podstawie danych z wieloletnich prognoz finansowych.

20 Zob. M. Jastrzębska, Finanse jednostek samorządu terytorialnego, Warszawa 2012, s. 188. 
Jak widać, tylko pięć miast (Białystok, Gdańsk, Katowice, Łódź i Zielona Góra) spośród osiemnastu, planuje w latach 2015-2018 wystąpienie deficytu jednokrotnie, zaś trzykrotnie - nadwyżkę (przeznaczoną z reguły na spłatę zobowiązań). Jest to dość zastanawiające, szczególnie przy uwzględnieniu rosnących kosztów wykonywania obligatoryjnych zadań własnych, jak też konieczności zapewnienia wkładu własnego na realizację zadań współfinansowanych chociażby ze środków Unii Europejskiej $^{21}$. Trzeba dodać, że takie optymistyczne budżety zazwyczaj skłaniają do krytycznego podejścia, rodzą podejrzenia, że zaplanowane w nich parametry finansowe są na wyrost i nie zostaną później w takiej wysokości osiągnięte. Analizując prognozy można zaobserwować tendencję zawyżania dochodów bieżących, jak też ze sprzedaży majątku. Warto też podkreślić, że zdecydowana większość największych miast w Polsce wykazuje deficyty w latach 2015-2018.

\section{Podsumowanie}

Problem wieloletniego planowania finansowego w samorządzie terytorialnym jest opisywany w literaturze przedmiotu od wielu lat. Nie ulega wątpliwości, że samo planowanie finansowe na poziomie samorządu nie należy do łatwych przedsięwzięć, a trudności z tym związane wynikają m.in. z:

- dużej skali zadań przekazanych poszczególnym jednostkom samorządowym (najwięcej gminom),

- nieadekwatnych środków finansowych - nawet na zadania zlecone przez administrację rządową,

- silnego wpływu czynnika politycznego na kształtowanie wielkości i struktury budżetu,

- istotnego wpływu czynników makroekonomicznych (inflacja, PKB) na wielkość dochodów budżetowych,

- odrębnych zasad planowania dochodów niż wydatków.

21 Możliwość absorpcji środków z UE przy realizacji projektów unijnych zależy przede wszystkim od zdolności do wygenerowania korzystnej tendencji kształtowania się nadwyżki operacyjnej (rozumianej jako różnica między dochodami bieżącymi a wydatkami bieżącymi) oraz od zdolności do pozyskiwania w odpowiednim czasie i w odpowiedniej wysokości środków pożyczkowych. W latach 2016-2020 duża część środków UE jest przewidziana na wdrażanie krajowych i regionalnych programów operacyjnych z przeznaczeniem na finansowanie projektów inwestycyjnych. Znaczącym beneficjentem tych środków będą jednostki samorządu terytorialnego, a w największym stopniu gminy. 
Z obserwacji wynika, że WPF jest często traktowana czysto mechanicznie, tj. poprzez wypełnienie poszczególnych kolumn i wierszy tabeli, w celu realizacji ustawowych wymogów nałożonych na jednostki samorządowe. Takie podejście nie ma nic wspólnego z działaniem efektywnym i racjonalnym.

Z przedstawionej analizy można sformułować wnioski o charakterze ogólnym. Po pierwsze, w dalszym ciągu brak jest wystarczających mechanizmów gwarantujących wiarygodność projektowanych parametrów finansowych. Można odnieść wrażenie, że wprowadzenie ustawowego obowiązku ${ }^{22}$ (który nie jest pozbawiony wad, mimo dokonanych zmian) przyczyniło się do fasadowego planowania wieloletniego, $\mathrm{tj}$. na zasadzie „co najwyżej spełnienia wymogów prawnych” (norm), na podstawie niejednokrotnie nierealnych założeń. Po drugie, WPF traktowana jako dokument strategiczny, paradoksalnie nadal jest dokumentem wtórnym do budżetu (dokumentu zarządzania bieżącego). Nadto, sprowadzana jest często do czysto formalnej postaci.

Po trzecie, brak realistyczności planowania w zakresie m.in. prognozy kwoty długu, czy też możliwości jego spłaty powoduje, że prognozy finansowe $\mathrm{w}$ samorządzie są opracowywane stricte $\mathrm{w}$ celu wypełnienia ustawowego obowiązku i na potrzeby pozyskania pozytywnych opinii regionalnych izb obrachunkowych. Stąd trudno je traktować jako istotny i pomocny instrument w zarządzaniu finansami samorządowymi. Po czwarte, należałoby wprowadzić do wieloletniej prognozy finansowej obligatoryjnej pozycji „wydatków stałych”. Po piąte, wieloletnią prognozę finansową traktuje się jako plan, tymczasem obrazuje to pewien chaos i niezrozumienie znaczenia pojęć. Plan w sensie teoretycznym stanowi spójny zbiór celów i zadań oraz dobór trafnych środków i metod ich realizacji. Programowanie zawiera te same elementy, ale ich połączenie ma charakter luźny. Zarówno plan, jak i program jest wynikiem procesu informacyjno-decyzyjnego, którego efekt jest przekazywany do wykonania. $\mathrm{Z}$ kolei prognoza ma charakter jedynie informacyjny (indykatywny), ma zwiększyć wartość podjętej decyzji. Trzeba dodać, że na poziomie centralnym ustawodawca wprowadził obowiązek tworzenia wieloletniego planu finansowego.

22 Narzuconego określonym wzorem, szablonem. 


\section{Bibliografia}

Czołpińska E., Wieloletnia prognoza finansowa - doświadczenia po roku stosowania. Przewidywania, praktyka i wnioski de lege ferenda, http://www. samorzad.lex.pl, (dostęp 20.07.2015).

Dylewski M., Wieloletnia prognoza finansowa, budżet a budżet zadaniowy - problemy i wyzwania, [w:] Budżet zadaniowy metoda racjonalizacji wydatków, red. Wożniak B., Postula M., Warszawa 2012.

Jastrzębska M., Finanse jednostek samorządu terytorialnego, Warszawa 2012.

Kosikowski C., Reforma finansów w Polsce w świetle nowej ustawy o finansach publicznych, „Państwo i Prawo” 2009, nr 12.

Kuzyniak E., Wirtualne dochody nie rozwiąża problemów wskaźnika zadłużenia, „Wspólnota” 2013, nr 20.
Owsiak S., Wieloletnie planowanie finansowe a funkcjonowanie budżetu zadaniowego, „Studia BAS” 2013, nr 1 (33).

Patrzałek L., Finanse samorządu terytorialnego, Wrocław 2010.

Ustawa z dnia 27 sierpnia 2009 r. o finansach publicznych (Dz.U.z 2013 r., poz. 885 ze zm.).

Ustawa z dnia 13 listopada 2003 r. o dochodach jednostek samorządu terytorialnego (Dz.U. z 2014 r., poz. 1115 ze zm.).

Wieloletnia prognoza finansowa jako instrument zarządzania finansami lokalnymi, red. Walczak P., Warszawa 2012.

Samorzad terytorialny w Polsce. Raport, red. Wojciechowski E., Łódź 2014. 